himself, and he also constructed a telescope on this principle many years ago in England without knowing that the method was engaging the attention of others. He sends an account of a mercurial reflecting telescope exhibited by him before the New Zealand Institute, Nov. 19, 1872, which is published in the Transactions of that Institute, vol. v. p. II9.

THE Times of Monday and Tuesday contains some interesting details concerning Col. Gordon's African Expedition from one of his staff. The latest date is June $\mathrm{I} 8$, when the various detachments were in boats on the White Nile, making the best of their way to Gondokoro. One of the objects of this expedition, as our readers ino doubt know, is to carry out the work so well begun by Sir Samuel Baker in the suppression of slavery. Col. Gordon expects to have steamers on Lake Albert Nyassa by November next; and the Rev. H. Waller, writing in the Times, states that by taking the Suez, Souakim, Berber, and Khartoum route, it is quite possible to reach Gondokoro in forty-eight days from England, including a week's rest at Khartoum.

IN the "Tijdschrift voor entomologie nitgegeven door de Nederlandsche entomologische vereeniging" is a useful paper On Acentropus (Curt.), by Mr. Ritsema. He refers to the passage in the preface to the Zoologist for 1857: "We have an aquatic section of Diptera, Neuroptera, Coleoptera and Hemiptera ; it is in perfect accordance with the known laws of Nature that there should be an aquatic section of Lepidoptera;" and he quotes the opinion given by Dr. Hagen in July 1856 , that Acentropusnivens is a lepidopterous insect of the family Crambidæ. $\mathrm{He}$ then gives in chronological order extracts from writers in different countries who regard Acontroputs as lepidopterous, and adds in conclusion a list of the streams and ponds where it has been found. Stephens, in 1835, raised the question whether his Acentropidce ought not to be placed under Lepidoptera, but Dr. Ritsema does not quote him.-There is also a continuation of a new catalogue of the Hymenoptera of the Netheriands, by Snellen van Vollenhoven, with localities and list of synonyms. 1,072 species are enumerated, of which $r_{3}$ are described in full as new to Science, -Dr. Ritsema describes the male of a Xylocopa, of which he says he knows only some eight or nine examples, and of which there is no specimen mentioned in the British Museum Catalogue. He gives two coloured figures.

AN Entomological Club has been formed at Cambridge, Massachusetts, having for its object the mutual interchange of discoveries and observations in regard to entomology. It has been determined to undertake the publication of a monthly organ to be called Psyche. This will contain such a part of the proceedings of the Society as are considered of general interest, communications, lists of captures, and especially a Bibliographical Record, in which will be given a list of all writings upon entomology published in North America, and all foreign writings upon North American entomology from the beginning of the year 1874 . The editor is Mr. B3. Pickman Mann, of Cambridge, Massachusetts. The first number contains an article by Mr. Scudder, on the English names for butterflies, and the first part of the Bibliographical Record.

We have received from the Royal Observatory, Cape of Good Hope, "The Cape Catalogue of 1, I59 Stars, deduced from Observations at the Royal Observatory, Cape of Good Hope, 1856 to 1861 , reduced to the epoch 1860 ," under the superintendence of E. J. Stone, F.R.S., H.M. Astronomer at the Cape.

WE learn from the Gardener's Chronicle that there is to be an exhibition of useful and noxious insects during next month at the Tuileries, Paris. The exhibition commences on the 6 th and is under the auspices of the Sociéte Générale d'Insectologie. In a country where the vines are being devastated by Phylloxera and where an epidemic disease has been spreading among the silk-worms, the value of such exhibilions cannot be over-estimated.

A FAPER by Mr. N. Whitley, C.E., entitled "The Palæo. lithic Age Examined," read before the Victoria Institute, has been published (Hardwicke) in a separate furm, along with the subsequent interesting discussion, in which Dr. W. B. Carpenter, F.R.S., Mr. John Evans, F.R.S., Mr. W. C. Borlase, Mr. Charlesworth, and others took part.

MessRs. BLACKwood and Sons have in the press and nearly ready for publication, "Economic Geology ; or, Geology in its relations to the Arts and Manufactures," by David Page, LL.D.

Messrs. Longman will shortly publish the following works bearing upon Science :- "The Primeval World of Switzerland," by $D_{1}$. Oswald Heer, translated from the German and edited by James Heywood, F.R.S. ; this work will be illustrated. "The Sun : an account of the principal modern discoveries respecting the Structure of the Sun of our System," by Father Secchi, translated and edited by Richard A. Procter. "The Star Deptlss ; or, other Suns than ours," by Richard A. Procter. "An Introduction to Experimental Physics," by Adolf F. Wermhold. And a new edition of Dr. Neil Arnott's "Elements of Physics," edited by Alexander Bain and Alfred Swain Taylor.

M. Göppert has issued a little "Guide to the Royal Botanic Garden of the University of Breslau," containing an interesting account of its various collections, and of the most important plants grown in it, illustrated by a map.

We have received Mr. Ellery's Monthly Record of observations taken at Melbourne Observatory in December and January last. The mean temperature in the former month was $672^{\circ}$, being $3.6^{\circ}$ higher than the last fifteen, years' average, "and the highest on record with one exception. The highest temperature in the shade was $101^{\circ} 2^{\circ}$, the range in the month being $56.3^{\circ}$.

THE most recently published parts of the new edition of "Griffiti and Henfrey's Micrographic Dictionary" bring the work down as far as "Mouth." The publication continues to maintain its high scientific character.

THE additions to the Zoological Society's Gardens during the past week include two Egyptian Gazelles (Gazella dorcas) from Egypt, presented by Mr. G. Muscat ; four Rufous Tinamons (Rhynchotus rufescens) from the Argentine Republic, presented by Mr. Alfred O. Lumb; three Mastigures (Uromastix sp. ?) from Persia, presented by Captain Phillips; one Yaguarundi Cat (Felis y'aguarundi) from South America, deposited.

\section{U. S. WEATHER MAPS}

THE American Fournal of Science and Arts for July contains an article on Results derived from an Examination of the United States Weather Maps for 1872 and 1873 , by Elias Loomis, Professor of Natural Philosophy in Yale College.

Prof, Loomis had a number of outline maps of the United States prepared, and on these he traced the tracks of all the storms, whenever a storm-centre could be satisfactorily located, for two successive days, the maps exhibiting, on the aggregate, storm-paths for 314 days. These results were then reduced to a tabular form by measuring with a protractor the bearing of each storm-path with reference to a meridian, and measuring the daily progress of the storm on a scale of inches. This table showed the date of each storm, the velocity of its progress, the direction of its path, together with readings of the barometer before, during, and after a storm, and from it were calculated the following:-The average direction of the storm-paths for two years was $8^{\circ}$ to the north of east, and the average velocity wa $25^{\circ} 6$ miles per hour. July is the month in which the course is most south, and October in which it is most north. February 
is the month of greatest, and August of least velocity, the former exceeding the latter by 75 per cent. In some instances a storm-centre has remained stationary for twenty-four hours, and in four cases it travelled $\mathrm{r}, 200$ miles in that time. In one case a speed of $57^{\circ} 5$ miles per hour was reached. In April 1873 a stom-centre changed its path $360^{\circ}$ in 24 hours. Taking into account the actual motion of a storm-centre from hour to hour, it seems that a storm-path may have every possible direction, and the velocity of progress may vary from 15 miles per hour westward to 60 miles per hour eastward.

'The fall of rain seems to have a clecided influence in modify. ing the course of a storm-path. The rainfall area is usually much larger to the east of a storm-centre than the west, 500 miles being the average length on the east side. There is a connection between the velocity of the storm's progress and the extent of this rain area--for example, when the eastern extent is roo miles greater than the mean (500 miles), then the hourly velocity increased 14.9 miles beyond the mean $\left(25^{\circ} 6\right)$, but when the eastcrn extent of the rain area is 100 miles less than the mean, the hourly velocity of the storm's progress is diminished 8 ' 1 miles.

As to the direction in which the rain area is most extended, the axes of the areas were compared with the storm-paths, and gave this result, that the average course of a storm-path for twentyfour hours coincides very closely with the position of the axis of the rain area for the preceding eight hours.

Prof. Loomis says: "The progress of a storm eastward is not wholly due to a drifing, resulting from the influence of an upper current of the atmosphere from the west, but the storm works its own way eastward in consequence of the greater precipitation on the eastern side of the storm. Thus the barometer is continually falling on the east side of the storm and rising on the west side, in consequence of the flowing in of colder air on that side."

In order to trace the influence of the wind's velocity upon the prosress of stoms, Prof. Loomis divides a circle into four quarliants, and by an arrow in each, showing the average direction of the wind, it is at once perceived that there is a strong cendency of the winds inward to the centre of the storm; but the average direction in each quadrant differed from what it wonld be if the wind revolved in a circle round the storm. centre.

The velocity is greatest in the west quadrant and diminishes in the successive quadrants as we pass round the circle from weat by south to north. On each side of the storm's centre the winci blows obliquely inward, and hence it is inferred that in the central region of the storm there is an upward motion of the air, and this is the cause of the precipitation of vapour; that is, the cause of the rainfall.

The average rise of a barometer for twenty-four hours in the rear of a storm is sensibiy greatest when the velocity of progress is greatest. Prof. Loomis believes it is possible to predict where a storn-centre will be at the end of twenty-four hours.

His inquiries into the relation between the velocity of the wind and the velocity of a storm's progress have led to the conclusion that at a height of $6,000 \mathrm{ft}$. in the western quadrant of a stom the velocity of the wind is 68 per cent. greater than the velocity with which the storm advances.

Fie then considers how to cletermine whether a storm is increasing or diminishing in intensity, and concludes that when the barometer rises more rapidly than usual as the storm passes by, the pressure at the centre of the storm is increasing; but when in the rear of the storm the barometer rises less rapidly than usual, the pressure on the centre is diminishing or the storm is increasing in intensity. Sections on "The Form of Isobaric Curves," on "The Classification of Storms," and "Where do the Storms which seem to come from the far west originate?" conclude the article.

\section{SCIENTIFIC SERIALS}

The Geological Magazine, August.-This number contains five original articles. I. Notes on fossil Orthoptera related to Gryllacris, by A. H. Swinton. The fossil remains are two from the eocene and three from the coal formation. The two eocene are, Gryllacris Ungeri of Heer, and G. Charpentieri of Heer. The coal species are, Gryllacris lithanthraca, two species, and Gryllacis [Corydalis] Brougniarti (Aud.). In the specimen G. Brousniurti there are indications of the "file," on which $\mathrm{Mr}$. Swinton remarks: "We see this ancient instrument of music had already attained to all appearance an efficiency at least thrice that of our modern house cricket, and must have emitted notes that rang widely over the tropical forests that clothed our island in the old days of the coal period."- -2 . On the Source of Volcanic Heat, by Mr. G. Poulett-Scrope. Four-and-a-half pages are occupied in disavowing the views "saddled" upon him by Mr. Mallet, and in saying that Mr. Mallet's " definition" is a statement of a series of conjectures.-3. On the Glacial Epoch, by $\mathrm{Mr}$. Croll. This is a continuation of the article commenced last month. The probable thickness of the Antarctic ice-cap was then considered, and now the results of the melting of a portion of it are calculated. The Antarcticice-cap is equal in area to $\mathrm{I}-23^{\circ} 46$ of that covered by the ocean ; therefore $25 \mathrm{ft} .6 \mathrm{in}$. melted off would raise the general level of the ocean one foot, and one mile melted would raise the level $200 \mathrm{ft}$. Mr. Croll takes for the time of his calculation the period when cold was increasing in the northern hemisphere and warmth in the southern. The lessening of ice-cap in the southern and an accumulation of ice in the northern would displace the centre of gravity of the earth leading to a rise in the sea-level in the northern hemisphere. This, with the rise resulting from the melting, $\mathrm{Mr}$. Croll calculates would give for the latitude of Edinburgh a rise of sea-level of 800 to $1,000 \mathrm{ft}$. The supposition of the subsidence of land during our glacial period may therefore, he argues, be dispensed with; and he proceeds to show how this theory avoids many difficulties which the ele. vation and subsidence theory leads to. Further: the oscillations of sea level resulting from the displacement of the earth's centre of gravity throw light on many obscure points connected with the geographical distribution of animals and plants. For example, during the warm periods the English Channel would be dry land, and during the cold animals might cross to England from the north upon a frozen sea. And still further : if we knew (I) the extent of the general submergence of the glacial epoch and (2) the present amount of ice in the southern hemisphere, we could determine whether or not the earth is fluid in the interior. - 4. Geological notes from the neighbourhood of Cairo, by John Mine. The article, which is too long for us to notice, is illustrated by a section ancl sketch maps. - 5. The Red Chalk in Xorkshire, by the Rev. J. F. Blake. The paper principally refers to the occurrence of Ammonites Deshayesi in the red chalk, in the pebble-beds below it, at Hunstanton, in the Specton clay, and in the gault of Folkestone. The chalk is a deep-sea deposit, and in the sinking of the land in Upper Cretaceous times the passage beds from the Upper Neocomian to the Aptien were laid down in various areas from various sources. A. Deshayesi evidently lingered on during the time these changes were taking place till the red chalk set in in Yorkshire and the gault at Folkestone. -Among the reports is a notice of the Cotswold Club visit to Bath and a résumé of a paper, read by Dr. Wright, On the genesis of the oolites.

Proccedings of the Liverpool Naturalists' Field Club, $1873 \cdot 74$, -This club, which is fourteen years old, we are glad to see continues in a flourishing condition as regards members and funds, and has, during the session $1873-74$, been doing a fair amount of work. The present number of the Proceedings contains the address of the president, the Rev. H. H. Higgins, at the annual meeting, in which he touches on a variety of topics more or less connected with Natural History; following this is a list, prepared by Mr. Higgins, of all works bearing on the Natural History of the district of Liverpool from 1705 to the present time. The club made ten excursions durmg the summer and autumn of 1873 , and an account of these, with the detailed results of some of them, occupies part of the number. Appended is a list of excursion prizes to be competed for this summer, and the names of last years' winners.

Proceedings of the Winchester and Hampshire Scientific and Literary Society, vol. I, part iii. (1872-3).-We learn from the Fourth Annual Report of the society that as a consequence of altering the rules so as to admit ladies, several ladies have become members. We are glad to see also that sections have been formed for the special study of botany, entomology, and zoology, and that work has already been done in each of these departments. During 1873 , eighteen papers have been read in the society, most of them on subjects connected with science. In an introductory lecture, the Rev. E. Firmstone gives an interesting résume of what is known about the "Star Depths." Among the other papers we would note an ingenious one On the probable origin of flints, by Mrr. A. Angell, jun. ; "The Heraldry of the World," a long paper, amply illustrated, by Miss Zornlin; 